\title{
Coronacrisis en de financiële verslaggeving van Nederlandse beursfondsen
}

\author{
Ruud G.A. Vergoossen, Ferdy van Beest
}

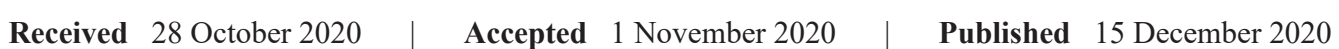

\section{Samenvatting}

In dit artikel wordt verslag gedaan van een onderzoek naar de effecten van de coronacrisis op de financiële verslaggeving - dat wil zeggen de jaarverslaggeving 2019 en de halfjaarverslaggeving 2020 - van in totaal 87 Nederlandse beursfondsen. Het is een studie naar de informatieverschaffing over de coronacrisis in het jaarverslag 2019 en het effect van de uitbraak van COVID-19 op het dividendbeleid van ondernemingen en op de snelheid waarmee de jaarrekening 2019 is vastgesteld. Daarnaast is de informatieverschaffing over de coronapandemie in de halfjaarverslaggeving 2020 en de invloed van COVID-19 op de winstgevendheid, de solvabiliteit, de hoogte van voorzieningen en de omvang van bijzondere waardeverminderingen in het eerste halfjaar van 2020 onderzocht.

De resultaten laten zien dat het uitbreken van de coronapandemie heeft geleid tot het later vaststellen van de jaarrekening 2019 en tot aanpassing van het dividendbeleid, met name in de financiële sector. Verder stellen we vast dat de winstgevendheid van de ondernemingen in het eerste halfjaar van 2020 duidelijk heeft te lijden onder de coronacrisis en constateren we een positief verband tussen de aandacht die er in de halfjaarverslaggeving 2020 is voor de coronapandemie en de omvang van de door ondernemingen genomen impairmentverliezen.

\section{Relevantie voor de praktijk}

Deze studie geeft inzicht in het effect van de coronapandemie op de jaarverslaggeving 2019 en halfjaarverslaggeving 2020 van Nederlandse beursgenoteerde ondernemingen en is relevant voor zowel controlerend accountants, toezichthoudende organen en regelgevende instanties als voor de opstellers en gebruikers van de financiële verslaggeving van ondernemingen.

\section{Trefwoorden}

jaarverslaggeving, halfjaarverslaggeving, beursfondsen

\section{Inleiding}

De uitbraak van COVID-19 (coronavirus disease 2019) die met name in de eerste helft van 2020 wereldwijd tot ingrijpende maatregelen heeft geleid, heeft grote economische gevolgen op de korte termijn en hoogstwaarschijnlijk ook op de lange(re) termijn. Sinds 11 maart 2020 wordt de uitbraak door de World Health Organization (WHO) erkend als pandemie. In Nederland zijn op 13 maart 2020 door de rijksoverheid de eerste maatregelen afgekondigd, gevolgd door extra maatregelen op 23 maart 2020 met als gevolg een 'intelligente lockdown'. Ook in andere Europese landen en landen buiten Europa zijn soortgelijke overheidsmaatregelen getroffen. In Nederland zijn vanaf juni 2020 de overheidsmaatregelen geleidelijk versoepeld, maar versoepelingen worden (regionaal) gedeeltelijk ongedaan gemaakt zodra het aantal coronabesmettingen weer toeneemt. In andere landen zijn vergelijkbare patronen waarneembaar.

In dit artikel doen we verslag van een onderzoek naar de invloed van de coronacrisis op de financiële verslaggeving 
van 87 ondernemingen waarvan aandelen zijn genoteerd aan Euronext Amsterdam (zie bijlage). Object van onderzoek is de jaarverslaggeving over het boekjaar 2019 waarbij het boekjaar gelijk is aan het kalenderjaar - en de halfjaarverslaggeving 2020, dat wil zeggen de halfjaarrekening die betrekking heeft op de eerste zes maanden van 2020 en het bijbehorende halfjaarlijkse bestuursverslag. ${ }^{1}$ De (geconsolideerde) jaarrekening en halfjaarrekening van de in het onderzoek betrokken ondernemingen zijn opgesteld op basis van de International Financial Reporting Standards (IFRS). Het manifest worden van de coronacrisis is voor de jaarverslaggeving 2019 een gebeurtenis na balansdatum die geen nadere informatie geeft over de toestand op balansdatum en die daarin als zodanig moet worden verwerkt, terwijl bij het opstellen van de halfjaarverslaggeving 2020 met de (mogelijke) effecten van de coronacrisis terdege rekening moet worden gehouden.

In de navolgende twee paragrafen zullen we de onderzoeksresultaten bespreken ten aanzien van de jaarverslaggeving 2019 respectievelijk halfjaarverslaggeving 2020. We sluiten af met enkele concluderende opmerkingen in de laatste paragraaf.

\section{Jaarverslaggeving 2019}

De jaarverslaggeving 2019 hebben we op de volgende aspecten onderzocht:

- de informatieverschaffing omtrent de coronacrisis;

- de snelheid waarmee de jaarrekening 2019 is opgemaakt/gepubliceerd en vervolgens is vastgesteld; en

- het dividendbeleid.

\subsection{Informatieverschaffing}

In ons onderzoek is de erkenning op 11 maart 2020 door de WHO van de uitbraak van het coronavirus als pandemie de cruciale gebeurtenis. Zoals gezegd, is dat voor de jaarverslaggeving 2019 een gebeurtenis na balansdatum. Bij gebeurtenissen na balansdatum wordt onderscheid gemakt tussen gebeurtenissen die nadere informatie geven over de situatie op balansdatum en gebeurtenissen waarbij dat niet het geval is. IAS 10, Events after the Reporting Period, spreekt over adjusting events after the reporting period respectievelijk non-adjusting events after the reporting period. Adjusting events moeten worden verwerkt in de jaarrekening indien die zich manifesteren voor de opmaakdatum, terwijl non-adjusting events in beginsel niet worden verwerkt in de jaarrekening, maar wel leiden tot informatieverschaffing in de toelichting en/of in het bestuursverslag. Alleen wanneer een non-adjusting event gepaard gaat met het vervallen van de continuïteitsveronderstelling wordt die in de jaarrekening - die dan wordt opgesteld op basis van liquidatiegrondslagen - verwerkt.

Van de in totaal 87 ondernemingen hebben 58 ondernemingen $(67 \%)$ hun jaarrekening voor of op 11 maart 2020 opgemaakt, terwijl 29 ondernemingen (33\%) hun jaarreke- ning 2019 na die datum hebben gedateerd. Het lijkt erop dat die 29 ondernemingen het begin van de coronacrisis hebben gezien als een non-adjusting event. In elk geval was die gebeurtenis voor hen geen aanleiding om de continuïteitsveronderstelling die aan de jaarrekening ten grondslag ligt, te laten vervallen. Waarschijnlijk zullen ook veel van de andere ondernemingen het begin van de coronacrisis hebben gekwalificeerd als een non-adjusting event, maar omdat ze op 11 maart 2020 hun jaarrekening al hadden opgemaakt, was een aanpassing van de jaarrekening sowieso niet opportuun. Dat geldt (uiteraard) niet voor ondernemingen die al in het najaar van 2019 zijn getroffen door de uitbraak van COVID-19 in China en andere delen van Azië, omdat ze daar belangrijke activiteiten hebben of afhankelijk zijn van leveranciers uit dat deel van de wereld.

Om te onderzoeken hoeveel aandacht er desalniettemin in de jaarverslaggeving 2019 is voor de coronacrisis, zijn we nagegaan:

- hoe vaak daarin de woorden 'corona' of 'COVID' (los of in samengestelde woorden) worden gebruikt;

- of de (mogelijke) invloed van de coronacrisis op de continuïteit van de ondernemingsactiviteiten expliciet aan de orde wordt gesteld;

- of in de controleverklaring een paragraaf is opgenomen ter benadrukking van de (mogelijke) invloed van de coronacrisis op de (continuïteit) van de ondernemingsactiviteiten.

In tabel 1 hebben we de onderzoeksresultaten weergegeven.

Tabel 1. Informatieverschaffing in de jaarverslaggeving 2019.

\begin{tabular}{l|r|r|r} 
& $\begin{array}{l}\text { Jaarrekening 2019 } \\
\text { opgemaakt voor of }\end{array}$ & $\begin{array}{l}\text { Jaarrekening } \\
\text { op 11 maart 2020 } \\
\text { na 11 maart 2020 }\end{array}$ & \multicolumn{1}{c}{ Totaal } \\
\hline Aantal ondernemingen & 58 & 29 & 87 \\
\hline $\begin{array}{l}\text { Gemiddeld aantal keren } \\
\text { 'corona' of 'COVID' }\end{array}$ & 1,38 & 13,86 & 5,54 \\
\hline $\begin{array}{l}\text { (Mogelijke) invloed op } \\
\text { continuïteit }\end{array}$ & $2(3 \%)$ & $17(59 \%)$ & $19(22 \%)$ \\
\hline $\begin{array}{l}\text { Paragraaf ter benadrukking } \\
\text { in controleverklaring }\end{array}$ & 0 & $10(37 \%)^{\mathrm{a}}$ & $10(12 \%)^{\mathrm{a}}$ \\
\hline
\end{tabular}

${ }^{a}$ Bij twee jaarrekeningen 2019 ontbreekt de controleverklaring. Dit betekent dat de percentages zijn gebaseerd op 27 respectievelijk 85 waarnemingen.

In tabel 1 komt duidelijk naar voren dat de datum waarop de jaarrekening 2019 is opgemaakt - dat wil zeggen voor/op dan wel na 11 maart 2020 - bepalend is voor de mate waarin informatie wordt gegeven over de coronacrisis in de jaarverslaggeving 2019.

Het blijkt dat de woorden 'corona' of 'COVID' gemiddeld 5,54 keer $(\sigma=8,27)$ in de jaarverslagen 2019 van de in het onderzoek betrokken ondernemingen worden gebruikt. Door 34 ondernemingen worden de woorden 'corona' of 'COVID' niet één keer gebruikt, maar dat zijn in alle gevallen ondernemingen die hun jaarrekening 2019 voor of op 11 maart 2020 hebben opgemaakt. In de jaarverslagen van ondernemingen die hun jaarrekening na 11 maart 2020 hebben opgemaakt, is er - logischerwijze - meer aandacht voor de coronacrisis en de (mogelijke) gevolgen daarvan. Ze 
Figuur 1. Illustratie van gebeurtenis na balansdatum inzake het begin van de coronacrisis: ASR, Annual report 2019, p.84. https:// www.asrnederland.nl/investor-relations/jaarverslagen

Coronavirus
In December 2019 , a pneumonia outbreak was reported in China which in 2020 rapidly developed into what
is now commonly referred to as the coronavirus. The virus has resulted in a significant number of confirmed
cases of infection in large portions of the world, including the Netherlands. Globally, governments are taking
various measures to contain the outbreak and to mitigate its impact on the economy. In the Netherlands, the
Dutch government issued a series of far reaching measures to stop the spread of the coronavirus. Both the
virus and the countermeasures have a significant impact on Dutch society and economics in the short term.
The government has also presented a significant economic relief program to support both companies and
individuals that are financially impacted by the corona outbreak. As the number of infections caused by the
virus is still increasing, and the result of both the countermeasures to the virus outbreak as well as the
economic relief program still has yet to take effect, the impact of the coronavirus is unsure, specifically in the
longer term.
At this point in time it is too early to make a realistic and credible assessment of what the impact of the
coronavirus will be on a.s.r.'s business and financial performance. The effect on our financial results will
depend on a number of factors, including the extent and duration of the period of disruption and the impact
on the global economy and financial markets. As published in this report, a.s.r. is financially healthy and its
capital position is solid. In the recent weeks, a.s.r.'s Solvency II ratio proved resilient to absorb these
extraordinary developments in the financial markets. Based on the closing market position as of 19 March
2020 , which is the most recent analysis available at the time of publication of this annual report, a.s.r.
estimates its Solvency II ratio, on the standard formula, to be substantially higher than year-end 2019 .
[...]

gebruiken gemiddeld 13,86 keer $(\sigma=9,31)$ de woorden 'corona' of 'COVID' tegen gemiddeld $1,38 \operatorname{keer}(\sigma=2,81)$ door ondernemingen die hun jaarrekening voor of op 11 maart 2020 hebben opgemaakt. In totaal 19 ondernemingen (22\%) bespreken in hun jaarrekening 2019 de (mogelijke) invloed van de coronacrisis op de continuïteit van de ondernemingsactiviteiten. Het betreft voornamelijk ondernemingen die hun jaarrekening na 11 maart 2020 hebben opgemaakt.

$\mathrm{Bij} 37 \%$ van de ondernemingen die hun jaarrekening 2019 na 11 maart 2020 hebben opgemaakt, heeft de externe accountant in de controleverklaring een paragraaf opgenomen ter benadrukking van de impact van de coronacrisis met daarin verwijzingen naar passages daarover elders in het jaarverslag. Overigens hebben we een controleverklaring aangetroffen waarin de externe accountant expliciet aangeeft de controlewerkzaamheden te hebben aangepast als gevolg van de coronacrisis: een geplande on-site review van controledossiers in Hong Kong is omgezet in een off-site review. Het betreft de controleverklaring d.d. 5 maart 2020 bij de jaarrekening 2019 van ASM International.

Ter illustratie bevat figuur 1 een passage over het begin van de coronacrisis die in de op 24 maart 2020 opgemaakte jaarrekening over 2019 van ASR is opgenomen als gebeurtenis na balansdatum.

\subsection{Opmaken/publiceren en vaststellen jaarrekening}

Op grond van de Wet op het financieel toezicht (artikel $5: 25 \mathrm{c} .1 \mathrm{Wft}$ ) moeten beursgenoteerde ondernemingen binnen vier maanden na afloop van het boekjaar hun jaarrekening opmaken en publiceren ('algemeen verkrijgbaar stellen'). De opgemaakte jaarrekening wordt vervolgens binnen twee maanden vastgesteld door de aandeelhoudersvergadering (zie artikel 394.2 BW 2). De European Securities and Markets Authority (ESMA) heeft naar aanleiding van de coronacrisis in een public statement aangegeven dat de bij ESMA aangesloten nationale toezichthouders op de financiële verslaggeving (voor Nederland is dat de Autoriteit Financiële Markten (AFM)) geen prioriteit zullen geven aan het handhaven van de viermaandstermijn voor het publiceren van de jaarrekening 2019 als die met maximaal twee maanden wordt overschreden (ESMA 2020b).

We hebben onderzocht of het bestempelen van COVID-19 als pandemie en de naar aanleiding daarvan getroffen rigoureuze maatregelen in Europa en andere delen van de wereld met mogelijk grote gevolgen voor het bedrijfsleven, het opmaken van de jaarrekening 2019 door de raad van bestuur en vervolgens het vaststellen van die jaarrekening door de aandeelhoudersvergadering hebben vertraagd. Daartoe hebben we de opmaak- en vaststellingstermijnen voor de jaarrekening 2019 vergeleken met die voor de jaarrekening 2018 van de in het onderzoek betrokken ondernemingen. De vergelijkingen hebben we in tabel 2 opgenomen.

Tabel 2. Opmaak- en vaststellingstermijnen jaarrekening (2019 versus 2018).

\begin{tabular}{l|r|r|r} 
& 2019 & 2018 & Verschil \\
\hline Opmaken: gemiddeld aantal dagen na balansdatum & 67,38 & 65,68 & 1,70 \\
\hline Vaststellen: gemiddeld aantal dagen na opmaken & 68,21 & 58.90 & $9,31^{*}$ \\
\hline$* \mathrm{p}<0,01$.
\end{tabular}

Uit tabel 2 kan worden afgelezen dat het begin van de coronacrisis gemiddeld genomen nauwelijks heeft geleid tot het later opmaken van de jaarrekening 2019. De 
Figuur 2. Illustratie van informatieverschaffing over onzekerheden veroorzaakt door COVID-19: RoodMicrotec, Annual report 2019, p.28. https://www.roodmicrotec.com/en/resources/downloads/investor-relations/annual-reports/annual-reports19-21/1490-roodmicrotec-annual-report-2019/file

Outlook
At this stage, it is not possible to reliably forecast either the duration of the COVID-19 disruption or its
impact on the Group's business and financial results for 2020 and 2021 . RoodMicrotec accordingly
withdraws all its earlier guidance for 2020 and 2021 and will provide further updates as and when
appropriate.
The spread of the COVID-19 virus together with the refinancing or extension of the maturity of the secured
bond loan, which is due and payable on 30 June 2021 have been identified as events that indicate the
existence of a material uncertainty that may cause substantial doubt about the company's ability to continue
as a going concern. Please refer to the paragraph 'Going concern basis of accounting' in the notes on page 55
to the consolidated financial statements.

gemiddelde opmaaktermijn voor de jaarrekening 2019 is 67,38 dagen $(\sigma=22,14)$ ten opzichte van 65,68 dagen $(\sigma=17,49)$ voor de jaarrekening 2018 . Dit kan voor een groot deel worden verklaard uit het feit dat twee derde van de ondernemingen op 11 maart 2020 hun jaarrekening al hadden opgemakt en veel andere ondernemingen toentertijd kort voor de afronding van het opmaken van de jaarrekening stonden. Wel zien we dat bij twee ondernemingen (Hydratec en RoodMicrotec) de maximale termijn van vier maanden is overschreden bij het opmaken van de jaarrekening 2019. Het lijkt erop dat ze gebruik hebben gemaakt van de 'faciliteit' die ESMA heeft geboden om in verband met de coronapandemie de termijn waarbinnen de jaarrekening 2019 moet worden gepubliceerd met twee maanden te verlengen. In de jaarrekening en de bijbehorende controleverklaring van beide ondernemingen wordt overigens gesproken over het bestaan van een materiële onzekerheid omtrent de continuïteit van de bedrijfsactiviteiten als gevolg van COVID-19.

In tegenstelling tot de opmaaktermijn heeft het uitbreken van de coronapandemie wel een statistisch significante invloed op de snelheid waarmee de jaarrekening wordt vastgesteld door de aandeelhoudersvergadering $(\mathrm{p}$ $=0,00)$. Het vaststellen van de jaarrekening 2019 heeft plaatsgevonden gemiddeld 68,21 dagen $(\sigma=25,76)$ nadat die is opgemaakt tegenover gemiddeld 58,90 dagen $(\sigma=$ 15,88 ) voor de jaarrekening 2018. Derhalve een verschil van gemiddeld 9,31 dagen $(\sigma=21,64)$.

Ter illustratie bevat figuur 2 een passage uit het jaarverslag 2019 van RoodMicrotec. De jaarrekening 2019 van RoodMicrotec is opgemaakt op 10 juni 2020 en vastgesteld op 23 juli 2020, terwijl de jaarrekening 2018 is opgemaakt op 4 april 2019 en vastgesteld op 23 mei 2019.

\subsection{Dividendbeleid ${ }^{2}$}

Aangezien de coronacrisis zich midden in het jaarverslagenseizoen heeft gemanifesteerd, is het interessant om vast te stellen in hoeverre dat heeft doorgewerkt in het dividendbeleid en heeft geleid tot een aanpassing van het uitgekeerde/uit te keren dividend. De aandeelhoudersvergaderingen van de in het onderzoek betrokken onderne- mingen waarop het (slot)dividend is vastgesteld, moesten immers nog plaatsvinden. Om dit te onderzoeken hebben we het dividendbeleid met betrekking tot het boekjaar 2019 vergeleken met het dividendbeleid met betrekking tot het voorafgaande boekjaar van dezelfde ondernemingen. Tabel 3 geeft weer hoe respectievelijk de winst per aandeel, het dividend per aandeel en de payout-ratio (dat is dividend per aandeel gedeeld door winst per aandeel) over 2019 zich gemiddeld verhouden tot de cijfers over 2018.

Tabel 3. Winst per aandeel, dividend per aandeel en payout-ratio (2019 versus 2018).

\begin{tabular}{|c|c|c|c|}
\hline & 2019 & 2018 & Verschil \\
\hline Winst per aandeel & $€ 1,68$ & $€ 1,68$ & $€-0,00$ \\
\hline Dividend per aandeel & $€ 0,69$ & $€ 1,01$ & $€-0,32 *$ \\
\hline Payout-ratio & 0,46 & 0,58 & $-0,12$ \\
\hline
\end{tabular}

$* \mathrm{p}<0,01$.

Tabel 3 laat zien dat de winst per aandeel over het boekjaar 2019 gemiddeld gelijk is aan de winst per aandeel over het boekjaar $2018(\sigma=2,39$ respectievelijk $\sigma=2,11)$. Op grond daarvan zou er geen reden zijn om de dividenduitkeringen naar beneden bij te stellen. Als we echter naar het dividend per aandeel kijken dan zien we dat dat wel is gebeurd en wel van gemiddeld $€ 1,01(\sigma=1,41)$ over het boekjaar 2018 naar gemiddeld $€ 0,69(\sigma=1,04)$ over het boekjaar 2019. De daling van het dividend per aandeel met gemiddeld $€ 0,32(\sigma=0,82)$ is statistisch significant ( $p$ $=0,00)$. Ook bij de payout-ratio zien we (dientengevolge) een daling. Die is gedaald van gemiddeld $0,58(\sigma=0,64)$ naar gemiddeld $0,46(\sigma=0,97)$. Het verschil van $0,12(\sigma=$ $0,83)$ is echter statistisch niet significant $(p=0,19){ }^{3}$

Aangezien vanwege de coronacrisis met name op ondernemingen in de financiële sector een beroep is gedaan om met dividenduitkeringen (ten minste) enige terughoudendheid te betrachten ${ }^{4}$, hebben we gekeken hoe de winst per aandeel, het dividend per aandeel en de payout-ratio van deze ondernemingen zich hebben ontwikkeld vergeleken met de ondernemingen in andere sectoren.

Tabel 4 toont de resultaten met betrekking tot verschillen tussen financiële en niet-financiële ondernemingen. De winst per aandeel bij ondernemingen in de financi- 
Tabel 4. Winst per aandeel, dividend per aandeel en payout-ratio: verschil tussen 2019 en 2018 (financiële sector versus andere sectoren).

\begin{tabular}{l|r|r|r} 
& \multicolumn{1}{l}{$\begin{array}{l}\text { Financiële } \\
\text { sector }\end{array}$} & \multicolumn{1}{l}{$\begin{array}{l}\text { Andere } \\
\text { sectoren }\end{array}$} & Verschil \\
$\begin{array}{l}\text { Winst per aandeel: verschil tussen } \\
2019 \text { en } 2018\end{array}$ & $€ 0,58$ & $€-0,11$ & $€ 0,69$ \\
\hline $\begin{array}{l}\text { Dividend per aandeel: verschil tussen } \\
2019 \text { en 2018 }\end{array}$ & $€-0,76$ & $€-0,25$ & $€-0,51^{*}$ \\
\hline $\begin{array}{l}\text { Payout-ratio: verschil tussen 2019 } \\
\text { en 2018 }\end{array}$ & $-0,65$ & $-0,02$ & $-0,63^{*}$ \\
\hline$* p<0,05$. & & & \\
\hline
\end{tabular}

ele sector is gestegen met gemiddeld $€ 0,58(\sigma=1,97)$, terwijl de winst per aandeel voor ondernemingen in de andere sectoren is gedaald met gemiddeld $€ 0,11(\sigma=$ $1,31)$. Het verschil van $€ 0,69(\sigma=0,43)$ is statistisch niet significant $(\mathrm{p}=0,11)$. Het dividend per aandeel over het boekjaar 2019 bij de ondernemingen die tot de financiële dienstverlening worden gerekend is gedaald met gemiddeld $€ 0,76(\sigma=0,68)$ vergeleken met het dividend per aandeel over het boekjaar 2018. Bij de ondernemingen in de andere sectoren is de daling gemiddeld $€ 0,25$ ( $\sigma=$ $0,82)$. Het verschil tussen beide categorieën van $€ 0,51$ $(\sigma=0,24)$ is statistisch significant $(\mathrm{p}=0,04)$. Ook bij de payout-ratio zien we (daardoor) een groot verschil tussen de financiële sector en de andere sectoren. In de financiële sector is de daling gemiddeld 0,65 $(\sigma=0,77)$, terwijl in de andere sectoren de daling met $0,02(\sigma=0,81)$ gemiddeld beperkt is. Het verschil tussen beide categorieën van 0,63 $(\sigma=0,24)$ is eveneens statistisch significant $(\mathrm{p}=0,01)$. Hiermee lijken de ondernemingen in de financiële sector gehoor te hebben gegeven aan de oproep om terughoudend te zijn met dividenduitkeringen.

\section{Halfjaarverslaggeving $2020^{5}$}

In de halfjaarverslaggeving 2020 komt de weerslag van de coronacrisis op de performance van de onderneming over de eerste zes maanden van 2020 tot uiting en moet rekening worden gehouden met mogelijke toekomstige effecten van de coronacrisis. We hebben onderzocht wat de invloed van de coronacrisis is op:

- informatieverschaffing in het halfjaarlijkse bestuursverslag;

- de winstgevendheid, de solvabiliteit en de voorzieningen;

- de bijzondere waardeverminderingen (impairments).

\subsection{Informatieverschaffing halfjaarlijkse bestuurs- verslag}

We hebben onderzocht of de in het onderzoek betrokken ondernemingen in hun halfjaarlijkse bestuursverslag 2020 informatie verstrekken over de volgende zaken:

- de invloed van COVID-19 op de onderneming en haar verwachtingen voor de toekomst, voor wat be- treft strategie, doelen, activiteiten, performance, financiële positie, kasstromen en dergelijke;

- het mogelijke effect van COVID-19 op de continuïteit van de ondernemingsactiviteiten;

- betalingsachterstanden als gevolg van COVID-19;

- problemen met de naleving van leningsconvenanten als gevolg van COVID-19;

- genomen of te nemen maatregelen om de gevolgen van COVID-19 op de onderneming aan te pakken of te mitigeren;

- aanpassing van huur/leasecontracten in verband met COVID-19;

- overheidsbijdrage(n), bijvoorbeeld in Nederland in het kader van de Tijdelijke Noodmaatregel Overbrugging voor Werkgelegenheid (NOW-regeling); ${ }^{6}$

- uitstel van betaling van belastingen in verband met COVID-19.

Deze informatie-elementen hebben we afgeleid van een public statement van ESMA (2020c) waarin aanbevelingen zijn opgenomen over de informatieverschaffing van beursgenoteerde ondernemingen in onder meer het halfjaarlijkse bestuursverslag. In tabel 5 hebben we weergegeven in hoeverre we bovenstaande informatie-elementen terugvinden in de halfjaarlijkse bestuursverslagen.

Tabel 5. Informatieverschaffing omtrent COVID-19 in halfjaarlijkse bestuursverslag $(\mathrm{N}=87)$.

\begin{tabular}{l|r|r|}
\hline $\begin{array}{l}\text { Informatie-element } \\
\begin{array}{l}\text { Invloed COVID-19 op onderneming en verwachtingen voor de } \\
\text { toekomst }\end{array}\end{array}$ & 85 & 98 \\
\hline Mogelijk effect van COVID-19 op continuïteit & 49 & 56 \\
\hline Betalingsachterstanden als gevolg van COVID-19 & 10 & 11 \\
\hline Problemen naleving leningsconvenanten als gevolg van COVID-19 & 18 & 21 \\
\hline $\begin{array}{l}\text { Maatregelen om gevolgen COVID-19 op onderneming aan te pakken } \\
\text { of te mitigeren }\end{array}$ & 70 & 80 \\
\hline Aanpassing van huur/leasecontracten in verband met COVID-19 & 7 & 8 \\
\hline Overheidsbijdrage(n), bijvoorbeeld in het kader van NOW-regeling & 28 & 32 \\
\hline Uitstel van betaling van belastingen in verband met COVID-19 & 18 & 21 \\
\hline
\end{tabular}

Uiteraard zullen niet alle informatie-elementen op alle ondernemingen van toepassing zijn. Opvallend is evenwel dat in het halfjaarlijkse bestuursverslag van twee ondernemingen helemaal niets wordt geschreven over de coronapandemie en de mogelijke gevolgen daarvan. Verder blijkt dat vier op de vijf ondernemingen maatregelen bespreken om de gevolgen van COVID-19 op de onderneming te beperken en dat meer dan de helft van de ondernemingen ingaat op het mogelijk effect van de coronacrisis op de continuïteit van de ondernemingsactiviteiten. Ook geven veel ondernemingen informatie over het gebruik van faciliteiten die overheden bieden: ongeveer een derde van de ondernemingen heeft het over overheidsbijdrage(n) en circa een op de vijf ondernemingen maakt melding van het uitstellen van de betaling van belastingen.

Als illustratie volgen hieronder delen uit een passage uit het halfjaarlijkse bestuursverslag 2020 van ABN AMRO. 
Figuur 3. Illustratie van informatieverschaffing over gevolgen coronapandemie in het halfjaarlijkse bestuursverslag 2020: ABN AMRO, Interim report \& quarterly report. Second quarter 2020, p.3. https://www.abnamro.com/nl/images/Documents/050_Investor_Relations/Financial_Disclosures/2020/ABN_AMRO_Bank_Quarterly_Report_2020_Q2.pdf

\begin{tabular}{|c|}
\hline 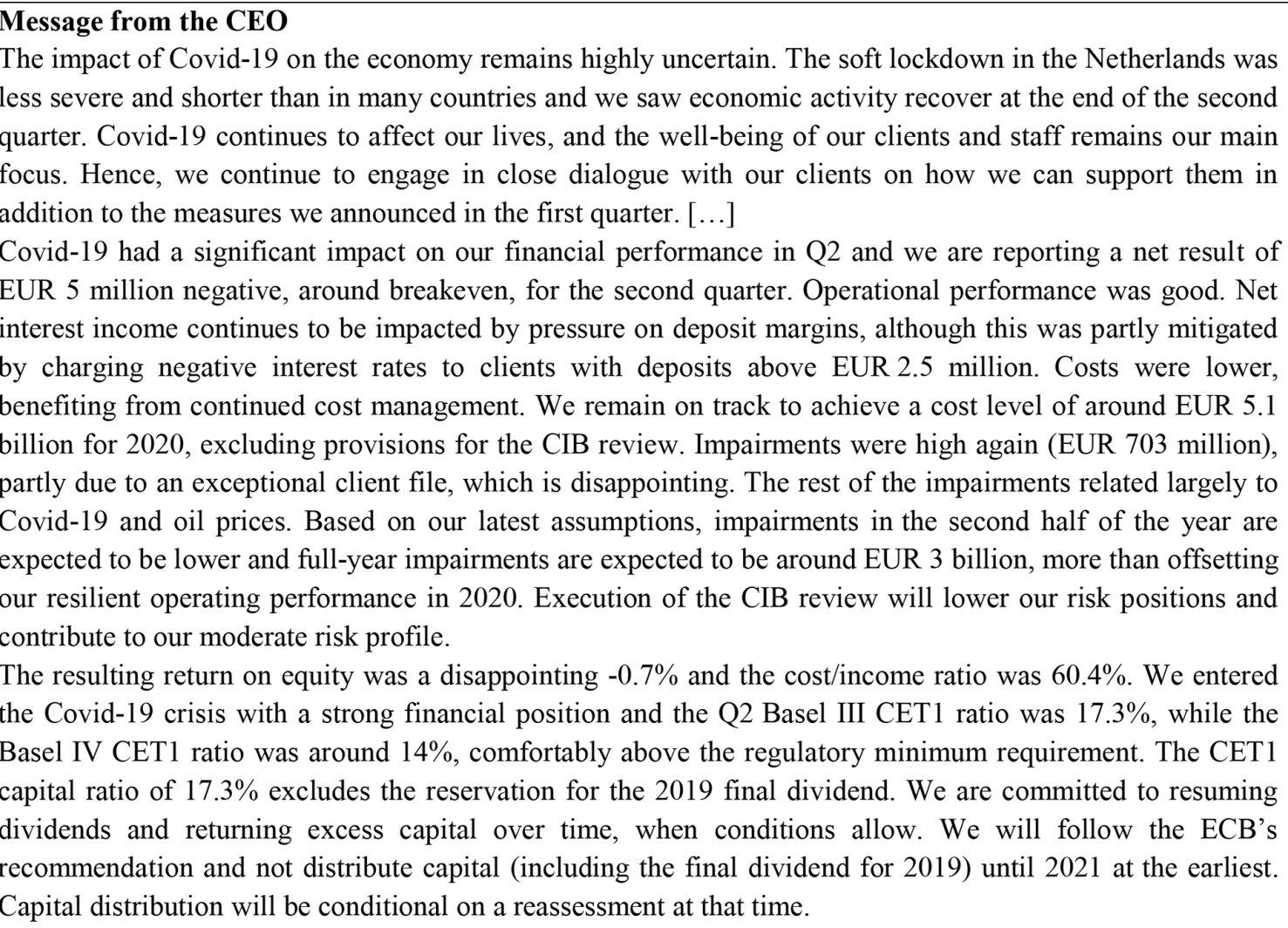 \\
\hline
\end{tabular}

\subsection{Winstgevendheid, solvabiliteit en voorzieningen}

Tabel 6 geeft de invloed weer van de coronacrisis op de winstgevendheid over het eerste halfjaar van 2020 en de solvabiliteit en de stand van de voorzieningen aan het einde van dat halfjaar. Als maatstaf voor de winstgevendheid hebben we de return on assets genomen, dat wil zeggen het nettoresultaat gedeeld door het totaal vermogen. De solvabiliteit meten we aan de hand van de equity ratio, dat is het eigen vermogen gedeeld door het totaal vermogen en de stand van de voorzieningen is het totaal van de voorzieningen op de creditzijde van de balans gedeeld door het balanstotaal. De winstgevendheid over het eerste halfjaar van 2020 vergelijken we met de winstgevendheid over dezelfde periode in 2019 , terwijl we de solvabiliteit en de stand van de voorzieningen op 30 juni 2020 vergelijken met de solvabiliteit en de stand van de voorzieningen op 31 december 2019.

Tabel 6. Invloed op winstgevendheid, solvabiliteit en voorzieningen.

\begin{tabular}{l|r|r|r} 
& \multicolumn{1}{l}{$\begin{array}{l}\text { Over eerste } \\
\text { halfjaar 2020 c.q. } \\
\text { per 30-06-2020 }\end{array}$} & $\begin{array}{l}\text { Over eerste } \\
\text { halfjaar 2019 c.q. } \\
\text { per 31-12-2019 }\end{array}$ \\
$\begin{array}{l}\text { Winstgevendheid (return on } \\
\text { assets) }\end{array}$ & $-0,3 \%$ & $3,3 \%$ & $-3,6 \% *$ \\
\hline Solvabiliteit (equity ratio) & $37,8 \%$ & $38,1 \%$ & $-0,3 \%$ \\
\hline Stand voorzieningen & $1,3 \%$ & $1,3 \%$ & $-0,0 \%$ \\
\hline$* \mathrm{p}<0,05$. & & &
\end{tabular}

Tabel 6 toont dat de gemiddelde winstgevendheid van de in het onderzoek betrokken ondernemingen is gedaald van 3,3\% $(\sigma=12,8 \%)$ over het eerste halfjaar van 2019 naar $-0,3 \%(\sigma=4,7 \%)$ over het eerste halfjaar van 2020 . Het gemeten verschil van $-3,6 \%(\sigma=14,5 \%)$ is statistisch significant $(\mathrm{p}=0,026)$. Ook de solvabiliteit is in het eerste halfjaar van 2020 gemiddeld genomen verslechterd, maar het verschil met de solvabiliteit aan het eind van het voorgaande boekjaar (31 december 2019) is betrekkelijk klein. De solvabiliteit is namelijk gedaald van $38,1 \%$ ( $\sigma$ $=21,7 \%)$ naar $37,8 \%(\sigma=22,2 \%)$. Het gemeten verschil $(-0,3 \% ; \sigma=7,4 \%)$ is statistisch niet significant $(p=0,733)$. De stand van de voorzieningen per 30 juni 2020, ten slotte, wijkt gemiddeld nauwelijks af van die op 31 december 2019. De exacte mutatie is $-0,034 \%$, afgerond $0,0 \%$.

Net als in paragraaf 2.3 , zijn we nagegaan hoe de financiële sector zich verhoudt tot de andere sectoren. Dit hebben we gedaan omdat (onder meer) ESMA (2020a) en de European Banking Authority (EBA 2020) hebben opgeroepen om bij de berekening van de verwachte kredietverliezen (expected credit losses) op basis van IFRS 9, Financial Instruments, de nodige terughoudendheid te betrachten. Het verzoek van genoemde toezichthouders komt er feitelijk op neer om impairments in verband met de coronapandemie niet te zwaar door te voeren vanwege het grote belang van de financiële sector voor de werking van de economie (El Barnoussi et al. 2020). 
In tabel 7 vergelijken we de winstgevendheid, de solvabiliteit en de stand van de voorzieningen van de financiële sector en de andere sectoren met elkaar.

Tabel 7. Verschil winstgevendheid, solvabiliteit en voorzieningen (financiële sector versus andere sectoren).

\begin{tabular}{l|r|r|r} 
& \multicolumn{2}{|c}{$\begin{array}{l}\text { Financiële } \\
\text { sector }\end{array}$} & Andere \\
sectoren & Verschil \\
$\begin{array}{l}\text { Winstgevendheid: verschil tussen eerste } \\
\text { halfjaar 2020 en eerste halfjaar 2019 }\end{array}$ & $-0,3 \%$ & $-4,1 \%$ & $3,8 \%$ \\
\hline $\begin{array}{l}\text { Solvabiliteit: verschil tussen 30-06-2020 } \\
\text { en 31-12-2019 }\end{array}$ & $2,4 \%$ & $-3,0 \%$ & $5,4 \%$ \\
\hline $\begin{array}{l}\text { Stand voorzieningen: verschil tussen } \\
\text { 30-06-2020 en 31-12-2019 }\end{array}$ & $-0,0 \%$ & $-0,0 \%$ & $0,0 \%$ \\
\hline
\end{tabular}

Tabel 7 toont dat de winstgevendheid van de ondernemingen in de financiële sector over het eerste halfjaar van 2020 gemiddeld nagenoeg gelijk is gebleven $(-0,3 \%$; $\sigma=0,02)$ vergeleken met het eerste halfjaar van 2019 . Bij de ondernemingen in de andere sectoren is gemiddeld sprake van een daling van $4,1 \%(\sigma=0,16)$. Het verschil is statistisch niet significant $(\mathrm{p}=0,38)$. Wellicht is het verschil tussen beide categorieën mede het gevolg van de mogelijkheid dat de ondernemingen in de financiële sector - in lijn met het public statement van ESMA (2020a) - relatief terughoudend zijn geweest bij het nemen van impairmentverliezen (expected credit losses). De solvabiliteit van ondernemingen in de financiële sector is in het eerste halfjaar van 2020 gemiddeld genomen verbeterd, terwijl die bij ondernemingen in de andere sectoren is verslechterd. Het verschil van 5,4\% $(\sigma=0,15)$ is echter statistisch niet significant $(p=0,72)$. Tot slot zien we geen verschil tussen beide sectoren voor wat betreft de stand van de voorzieningen.

\subsection{Bijzondere waardeverminderingen}

Als gevolg van de coronapandemie en de daarmee gepaard gaande verslechterde economische omstandigheden en vooruitzichten, zullen veel ondernemingen in de halfjaarverslaggeving 2020 rekening moeten houden met bijzondere waardeverminderingen (impairments). In IAS 36, Impairment of Assets, wordt in paragraaf 12 een aantal aanwijzingen voor bijzondere waardeverminderingen genoemd die in dat kader relevant zijn, zoals:

- de reële waarde van een actief/kasstroomgenererende eenheid is aanzienlijk sneller gedaald dan gebruikelijk;

- in de marktomstandigheden of omgevingsfactoren van de onderneming hebben zich of zullen zich in de nabije toekomst belangrijke wijzigingen voordoen die nadelig zijn voor de onderneming;

- het eigen vermogen van de onderneming is hoger dan de beurswaarde van de onderneming.

Aan de hand van een multivariate regressieanalyse hebben we getoetst in hoeverre de in het eerste halfjaar van 2020 genomen bijzondere waardeverminderingen kunnen worden toegeschreven aan het uitbreken van de coronapandemie. Voor de multivariate analyse gebruiken we de volgende regressie:

\section{LnImpairments $=\alpha+\beta_{1}$ Corona $+\beta_{2}$ Overheidsbijdra- ge $+\beta_{3} \Delta$ Dagen $+\beta_{4} E V>B W+\beta_{5}$ Sector $+\beta_{6} A E X /$ $A M X+\beta 7$ LnBalanstotaal $+\beta 8$ Winstgevendheid $+\beta 9$ Solvabiliteit $+\varepsilon$ \\ Afhankelijke variabele:}

- LnImpairments: is natuurlijk logaritme van de totale impairments (impairments van goodwill + impairments van (overige) immateriële vaste activa + impairments van materiële vaste activa + impairments van financiële vaste activa).

\section{Onafhankelijke variabelen:}

- Corona: is de ratio van het aantal keer dat het woord 'Corona' of 'COVID' (losstaand of in woordsamenstellingen) voorkomt in het halfjaarverslag gerelateerd aan de omvang (het aantal pagina's) van het halfjaarverslag. ${ }^{7}$ Dit nemen we als een maatstaf (proxy) voor het belang van de coronapandemie voor de onderneming, dat wil zeggen hoe vaker die woorden naar verhouding worden gebruikt hoe groter we de invloed van de coronapandemie op de onderneming achten.

- Overheidsbijdrage: is 1 als overheidsbijdrage(n) is (zijn) verkregen, anders 0 . Hier verwachten we hogere impairmentverliezen bij ondernemingen die een beroep doen op overheidsbijdrage(n).

- $\Delta$ Dagen: is het verschil in het aantal dagen tussen balansdatum en publicatiedatum van het halfjaarverslag 2020 vergeleken met het halfjaarverslag 2019. Als gevolg van mogelijke discussies over te nemen bijzondere waardeverminderingen, verwachten we een positief verband tussen het verschil in aantal dagen en de omvang van de impairmentverliezen.

- $\quad \mathrm{EV}>\mathrm{BW}$ : is 1 indien eigen vermogen van de onderneming hoger is dan haar beurswaarde, anders 0 . Dit wordt in IAS 36 gezien als een indicatie voor impairment op grond waarvan moet worden beoordeeld of daar daadwerkelijk sprake van is.

- Sector: is 1 indien onderneming behoort tot financiële sector, anders 0 . In de financiële sector verwachten we een effect van de relatief sterke focus in deze sector op de waardering tegen reële waarde en van het public statement van ESMA (2002a) over impairment onder IFRS 9 dat mogelijk van invloed is op het beleid ten aanzien van het verantwoorden van verwachte kredietverliezen (expected credit losses).

\section{Controlevariabelen:}

- AEX/AMX: is 1 indien er sprake is van een AEXof AMX-notering, anders 0. Dit onderscheid kan 
worden gezien als een maatstaf voor de 'zichtbaarheid' van ondernemingen.

- LnBalanstotaal: is omvang op basis van het natuurlijk logaritme van het balanstotaal per 30 juni 2020 .

- Winstgevendheid: is nettoresultaat/totaal vermogen (return on assets).

- Solvabiliteit: is eigen vermogen/totaal vermogen (equity ratio).

Tabel 8. Multivariate regressieanalyse impairments.

\begin{tabular}{lcr}
\multicolumn{1}{c}{$\boldsymbol{\beta}$} & \multicolumn{2}{c}{ Significantie (p) } \\
(Constant) & $-9,900$ &, 054 \\
Corona & 2,563 &, 593 \\
Overheidsbijdrage &,- 501 &, 158 \\
$\Delta$ Dagen &,- 063 &, 791 \\
EV $>$ BW &,- 232 &, 467 \\
Sector &,- 683 &, 973 \\
AEX/AMX &, 029 &, $000 * *$ \\
LnBalanstotaal & 1,058 &, 108 \\
Winstgevendheid & $-15,829$ &, 104 \\
Solvabiliteit & 3,179 & 0,580 \\
Adjusted $R^{2}$ & & \\
*** Significant op $95 \%$ - respectievelijk $99 \%$-niveau, bij tweezijdige toetsing.
\end{tabular}

Tabel 8 toont de regressieresultaten rondom de impairmentverliezen die in het eerste halfjaar van 2020 in totaal zijn genomen, dat wil zeggen de impairments van goodwill, (overige) immateriële vaste activa, materiële vaste activa en financiële vaste activa gezamenlijk. Het blijkt dat er - zoals verwacht - een positief statistisch significant verband is tussen de aandacht die er in het halfjaarverslag 2020 is voor de coronapandemie en de over het eerste halfjaar van 2020 verantwoorde impairmentverliezen ( $\beta$ $=2,56 ; \mathrm{p}=0,02)$. We zien geen statistisch significante verbanden tussen de andere onafhankelijke variabelen en de hoogte van de impairments. Bij de controlevariabelen is er wel nog een positief statistisch significante relatie tussen de omvang van de onderneming en de in het eerste halfjaar van 2020 genomen impairmentverliezen, dat wil zeggen naarmate de onderneming groter is, zijn de impairments hoger.

De verklarende kracht van het model - gebaseerd op de adjusted $R^{2}-$ is $58 \%$.

\section{Concluderende opmerkingen}

De erkenning door de WHO op 11 maart 2020 van de uitbraak van het coronavirus als pandemie is voor de jaarverslaggeving 2019 een gebeurtenis na balansdatum die geen nadere informatie geeft over de toestand op balansdatum. Dit betekent dat die gebeurtenis alleen in een (nog niet opgemaakte) jaarrekening wordt verwerkt als die gepaard zou gaan met het vervallen van de continuïteitsveronderstelling. Bij geen enkele onderneming uit ons onderzoek blijkt dat het geval te zijn. Wel zien we dat in de jaarverslaggeving 2019 veel meer informatie wordt verschaft over de uitbraak van COVID-19 en de (mogelijke) gevolgen daarvan voor de onderneming als de jaarrekening 2019 na 11 maart 2020 is opgemaakt. Daarnaast blijkt de coronacrisis te hebben geleid tot het later vaststellen van de jaarrekening 2019 door de aandeelhoudersvergadering en tot aanpassingen in het dividendbeleid. Dat laatste is vooral duidelijk waar te nemen in de financiële sector.

De invloed van de coronapandemie komt - uiteraard nog sterker naar voren in de halfjaarverslaggeving 2020. Zo bespreekt $98 \%$ van de ondernemingen de invloed van COVID-19 op de onderneming en haar toekomstverwachtingen en geeft $80 \%$ aan welke maatregelen zijn, worden of kunnen worden genomen om de gevolgen van COVID-19 te beperken. Ook wordt door meer dan de helft van de ondernemingen expliciet ingegaan op het mogelijk effect van de coronacrisis op de continuïteit van de ondernemingsactiviteiten.

De directe financiële gevolgen van de coronacrisis zien we in de halfjaarrekening 2020 met name bij de winstgevendheid. Gemiddeld genomen is de winstgevendheid significant gedaald, vergeleken met die over het eerste halfjaar van 2019. Dit geldt overigens niet voor ondernemingen in de financiële sector. Hun winstgevendheid is nagenoeg gelijk gebleven. Wellicht is dit mede het gevolg van de mogelijkheid dat ze relatief terughoudend zijn geweest bij het nemen van impairmentverliezen. De solvabiliteit en de stand van de voorzieningen zijn in het eerste halfjaar van 2020 - zowel in de financiële sector als in de andere sectoren - over het algemeen niet significant gewijzigd.

Tot slot hebben we een multivariate regressieanalyse uitgevoerd om te onderzoeken in hoeverre de in het eerste halfjaar van 2020 genomen impairmentverliezen samenhangen met de coronapandemie. Hier constateren we een statistisch significant positief verband tussen de aandacht die er in de halfjaarverslaggeving 2020 is voor de coronapandemie en de omvang van de verantwoorde impairments. Verder hebben we geen verbanden gevonden die kunnen worden gerelateerd aan de coronacrisis.

Al met al zien we dat COVID-19 een belangrijk thema is in zowel de jaarverslaggeving 2019 als de halfjaarverslaggeving 2020. Ook lijkt er vooral in de financiële sector sprake te zijn van invloed van toezichthouders op het dividendbeleid en de financiële verslaggeving van ondernemingen.

Bij het trekken van conclusies ten aanzien van de coronacrisis en het effect daarvan op de financiële verslaggeving moeten we enige voorzichtigheid betrachten. De populatie van Nederlandse beursgenoteerde ondernemingen is relatief klein en zou uitgebreid kunnen worden met andere Europese beursfondsen. Daarnaast worden de gevolgen waarschijnlijk nog meer zichtbaar in de jaarverslaggeving over het gehele boekjaar 2020. Als laatste - en dat kunnen we op dit moment eenvoudigweg niet inschatten - weten we niet hoe lang de wereld nog in de greep zal zijn van corona en hoe verstrekkend de gevolgen daarvan verder zullen gaan zijn. 
- Prof. dr. R.G.A. Vergoossen RA is hoogleraar Externe Verslaggeving en directeur Center for Corporate Reporting, Finance \& Tax, Nyenrode Business Universiteit en hoogleraar International Financial Accounting, Universiteit Maastricht.

- Dr. F. van Beest is assistant professor Externe Verslaggeving, Nyenrode Business Universiteit en manager Data Proposities en Integrated Reporting, Flynth adviseurs en accountants.

\section{Noten}

1. Ondernemingen met gebroken boekjaren hebben we niet meegenomen in ons onderzoek

2. In deze paragraaf hebben we één onderneming (outlier) uit de onderzoekspopulatie verwijderd, vanwege de extreem hoge payout-ratio (11,11).

3. Overigens kan de payout-ratio bij een onderneming hoger zijn dan 1 (namelijk als de dividenduitkering hoger is dan de nettowinst) of zelfs negatief (namelijk als er in een verliessituatie toch tot dividenduitkering wordt besloten).

4. Zie bijvoorbeeld: ECB wil dat banken voorlopig geen dividend uitkeren (30 maart 2020), https://www.banken.nl/nieuws/22295/ecb-wil-dat-banken-voorlopig-geen-dividend-uitkeren; EIOPA urges (re)insurers to temporarily suspend all discretionary dividend distributions and share buy backs (2 april 2020), https://www.eiopa.europa.eu/content/eiopa-urges-reinsurers-temporarily-suspend-all-discretionary-dividend-distributions-and_en

5. Bij ondernemingen die kwartaalberichten publiceren, betreft het de kwartaalverslagen over het tweede kwartaal van 2020 met daarin ook de (cumulatieve) cijfers over het gehele eerste halfjaar van 2020.

6. De NOW-regeling bood ondernemingen de mogelijkheid een groot deel van hun loonkosten vergoed te krijgen als ze verwachtten ten minste $20 \%$ omzet te verliezen.

7. Het aantal keer dat die woorden in de onderzochte halfjaarverslagen over 2020 voorkomen varieert van 0 tot 137 en is gemiddeld 25 . Gerelateerd aan de omvang van het halfjaarverslag varieert het aantal keer van 0,0 tot 2.3 per pagina en is het gemiddelde 0,7 keer per pagina.

\section{Literatuur}

El Barnoussi A, Howieson B, Van Beest F (2020) Prudential application of IFRS 9: (Un)Fair reporting in COVID-19 crisis for banks worldwide?! Australian Accounting Review 30(3): 178-192. https:// doi.org/10.1111/auar.12316

- EBA [European Banking Authority] (2020) Statement on the application of the prudential framework regearing Default, Forbearance and IFRS 9 in light of COVID-19 measures, 25 March 2020. https://eba.europa.eu/eba-provides-clarity-banks-consumersapplication-prudential-framework-light-covid-19-measures

- ESMA [European Securities and Markets Authority] (2020a) Accounting implications of the COVID-19 outbreak on the calculation of expected credit losses in accordance with IFRS 9, Public Statement, 25 March 2020, ESMA32-63-951. https:/www.esma.europa. eu/sites/default/files/library/esma32-63-951_statement_on_ifrs_9 implications_of_covid-19_related_support_measures.pdf

- ESMA [European Securities and Markets Authority] (2020b) Actions to mitigate the impact of COVID-19 on the EU financial markets regarding publication deadlines under the Transparency Directive, Public Statement, 27 March 2020, ESMA31-67-742. https://www.esma.europa.eu/sites/default/files/library/esma31-67742 ppublic_statement_on_publication_deadlines_under_the_td.pdf

- ESMA [European Securities and Markets Authority] (2020c) Implications of the COVID-19 outbreak on the half-yearly financial reports. Public Statement, 20 May 2020, ESMA32-63-972. https://www.esma. europa.eu/sites/default/files/library/esma32-63-972_public_statement_on_half-yearly_financial_reports_in_relation_to_covid-19.pdf

\section{Bijlage}

\section{In het onderzoek betrokken beursfondsen}

\section{AEX}

ABN AMRO

Adyen

AEGON

Ahold Delhaize

Akzo Nobel

Arcelor Mittal

ASM International

ASML

ASR

\section{DSM}

Galapagos

Heineken NV

IMCD

ING

Just Eat Takeaway

KPN

NN Group

Philips

Randstad

RELX

Royal Dutch Shell 
Unibail Rodamco Westfield

Unilever

Wolters Kluwer

AMX

Aalberts

Air France-KLM

Altice Europe

Aperam

Arcadis

BAM

Basic-Fit

BESI

Boskalis

Corbion

Fagron

Flow Traders

Fugro

GrandVision

Intertrust

NSI

OCI

Pharming

PostNL

SBM Offshore

Signify

TKH

Vopak

WDP

\section{AScX}

Accell

Acomo

Alfen

AMG

Avantium
B\&S Group

Brunel

ForFarmers

Heijmans

ICT

Kendrion

Nedap

Neways

NIBC

Ordina

SIF Holding

Sligro

TomTom

Van Lanschot Kempen

VastNed

Vivoryon

Wereldhave

Lokale markt

Ageas

AND International

BeterBed

Brill

CocaCola European Partners

Ctac

DPA

Eurocastle

Euronext

HAL Trust

Hunter Douglas

Hydratec

Klépierre

RoodMicrotec

Stern

Value8

Veon 